\title{
Bushmeat hunting around Lomami National Park, Democratic Republic of the Congo
}

\author{
Rodrigue Batumike, Gerard Imani, Christian Urom and Aida Cuni-Sanchez
}

\begin{abstract}
For most of the Democratic Republic of the Congo quantitative data on bushmeat exploitation are scarce. We conducted focus group discussions on preferred species for household consumption and income generation in 24 villages around Lomami National Park, created in 2016. We also carried out a bushmeat market survey in Kindu, a major town in the study area, to estimate annual sales volumes and retail values. Villagers reported household consumption of 22 mammal species, with the most important being the African brush-tailed porcupine, Peters's duiker, bay duiker and red river hog. The latter three were also the most important for income generation. A greater number of smaller species were consumed at the household level, compared with those traded. A total of $17 \mathrm{mammal}$ and one reptile species were traded in Kindu. Those traded in greater numbers were the African brush-tailed porcupine, blue and bay duiker, red river hog, red-tailed monkey and the sitatunga. We estimated $>40,000$ carcasses were traded in Kindu annually, with a retail value of USD 725,000 . Several species of conservation concern, such as the bonobo, were mentioned or observed. Few rodents and numerous large animals were traded in Kindu, suggesting resources have not yet been depleted. However, both villagers and urban vendors perceived a decline of many species and reported an increase in the use of firearms and the number of foreign hunters in the area. Among other interventions, we discuss how local communities could be encouraged to help preserve wildlife in the Park's buffer zone.
\end{abstract}

Keywords Bushmeat consumption, bushmeat trade, communities, Democratic Republic of the Congo, Lomami National Park, rainforest, wildlife conservation

Supplementary material for this article is available at doi.org/10.1017/So030605319001017

\footnotetext{
Rodrigue Batumike Département de Sciences de l'Environnement, Université du Cinquantenaire Lwiro, Kabare, Suk-Kivu, Democratic Republic of the Congo

GERARD ImANI (Corresponding author) Biology Department, Université Officielle de Bukavu, Bukavu, Democratic Republic of the Congo

E-mail imanigerard2006@yahoo.fr

Christian Urom Biology Department, Université de Kisangani, Kisangani, Democratic Republic of the Congo

AIDA CUNI-SANCHEZ (Corresponding author, (D) orcid.org/0000-0001-8619-1095) York Institute for Tropical Ecosystems, Department of Environment and Geography, University of York, York, UK

E-mail a.cunisanchez@york.ac.uk

Received 29 March 2019. Revision requested 12 June 2019.

Accepted 16 August 2019. First published online 5 March 2020.
}

\section{Introduction}

T $\mathrm{n}$ tropical forests, where wildlife biomass is lower than in more open habitats such as savannahs, overhunting of wild animals for their meat, often referred to as bushmeat, may lead to the depletion of local populations and can contribute to the extinction of some species (Abernethy et al., 2013). In Africa rising demand for bushmeat, related to human population growth and increased affluence, has led to a dramatic increase in bushmeat commercialization and hunting rates, threatening the populations of many targeted species (Bennett et al., 2002). Overhunting can have cascading effects in an ecosystem, affecting species not targeted for bushmeat (e.g. large carnivores) and altering forest structure and composition because large mammals and birds are important dispersers of trees with large seeds (Wright et al., 2000; Maisels et al., 2001). Because of these cascading effects, overhunting can also affect forest carbon stocks (Brodie \& Gibbs, 2009). In Africa unsustainable hunting of wild animals has been identified as the greatest threat to protected areas (Schulze et al., 2018).

In all Central African countries bushmeat is a significant source of animal protein and is important for food security (Fa et al., 2003). It is also often the only source of iron and fat (Siren \& Machoa, 2008; Golden et al., 2011). A recent study from Kisangani in the Democratic Republic of the Congo (DRC) showed that both wealthy and impoverished urban households consume bushmeat for a variety of reasons, including low cost and taste preference (van Vliet et al., 2015). Apart from being a crucial source of food and nutrients, bushmeat can also be an important source of income for rural communities (Fa et al., 2003; Mbete et al., 2011). Unsustainable hunting of wild animals can thus negatively affect the nutrition, food security and livelihoods of the people that depend on them.

Two approaches are often used to indirectly infer the sustainability of bushmeat hunting in a given area: hunting profiles (e.g. distance travelled on hunting trips), and market profiles (e.g. the range of species traded and price changes; $\mathrm{Fa}$ et al., 2000). In West and Central Africa the latter approach has gained attention because markets are highly visible (sale of most bushmeat is not illegal) and it is relatively easy to collect data on the animals for sale (Fa, 2007; Taylor et al., 2015). In areas with higher hunting pressures fewer large-bodied animals are sold at markets, and generally there is greater species diversity of the bushmeat on offer (Cowlishaw et al., 2005; Fa, 2007). This is because smaller-bodied species such as large rodents and small 
duikers possess higher reproductive potentials and are thus more resilient to heavy hunting pressure (Dupain et al., 2012; Fa et al., 2015). Large rodents and small duikers also survive in more degraded habitats (Kümpel et al., 2010). Despite their advantages, market surveys have limitations: what reaches a market is often only a subset of the species hunted (Cowlishaw et al., 2005). Although large-bodied animals are generally sold at urban markets, smaller and less valuable animals are more likely to be consumed by the hunters (Allebone-Webb et al., 2011). Hunters may also consume animals that are in too poor a condition to be sold and may trade some animals at the village level. Therefore, understanding hunters' household consumption is required to obtain a comprehensive view of bushmeat hunting in a given area.

Lomami National Park was created in July 2016, following a new law promulgated in DRC that considered sustainable development of protected area edge communities. This new Park has a large buffer zone in which local communities are allowed to carry out certain extractive activities (including hunting) to satisfy their needs (Mushagalusa, 2016). To provide insights into current hunting patterns in this Park, we combined village surveys and a market survey in Kindu (the largest urban centre near this Park), aiming to answer the following three questions: (1) Which species are used for household consumption and trade? (2) What are the economic values and annual volumes traded in Kindu? (3) Do local hunters or vendors perceive a decline of some species? Our relatively rapid assessment method can be of practical value to support conservation and sustainable use of wildlife in Lomami National Park and other reserves in the Congo Basin.

\section{Study area}

The $8,879 \mathrm{~km}^{2}$ Lomami National Park has a buffer zone of c. $20,000 \mathrm{~km}^{2}$ (Fig. 1). Most of the area is covered by lowland semi-evergreen rainforests, evergreen rainforests dominated by limbali Gilbertiodendron dewevrei, swamp forests and savannahs. The climate is equatorial, with a mean annual rainfall of c. 1,600 $\mathrm{mm}$ and mean monthly temperature of $23-26{ }^{\circ} \mathrm{C}$ (ICCN, 2012). The dry season (June-July) lasts $<2$ months. The Park provides habitat for threatened iconic species including the forest elephant Loxodonta africana cyclotis, bonobo Pan paniscus, okapi Okapia johnstoni, Congo peafowl Afropavo congensis, the recently discovered dryas monkey Cercopithecus dryas, only previously known from Salonga National Park, and the newly described lesula monkey Cercopithecus lomamiensis. The main inhabitants of the region are farmers practicing smallscale subsistence agriculture (cassava, maize and rice), hunting and fishing. Inhabitants also include Mbote (Pygmy) hunter-gatherers.

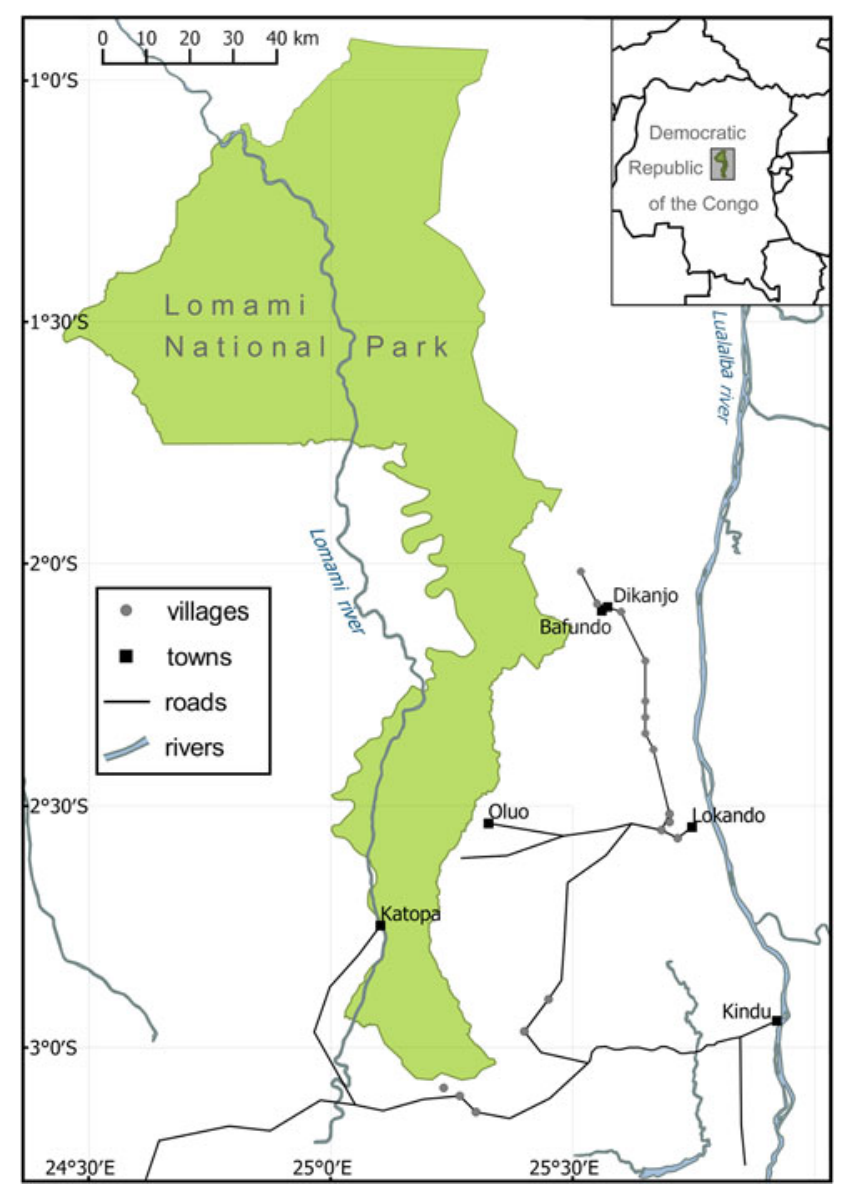

FIg. 1 Lomami National Park, major rivers, roads and towns, and villages sampled. Some villages are located next to each other and appear as one point on the map (we carried out surveys in a total of 24 villages).

\section{Methods}

\section{Village surveys}

We organized focus group discussions in 24 villages located around the southern part of the Park, which has more villages and is more easily accessible by road than the northern part (Fig. 1). Inhabitants belonged to six ethnic groups: Kusu, Kuti, Ngengele, Silwamba, Tetela and Mbote, each represented by four villages. Each focus group discussion involved 4-8 village elders including the village chief, as is customary in the area. After we explained the aim of the study to the village chief, he explained it to the elders and some decided to participate on a voluntary basis. All elders, including the chiefs, were active hunters, as this is the major livelihood activity in the study area, and is culturally important. None of the villages studied have access to electricity, running water or the mobile phone network. There are few primary schools and health centres in the region (often $>20 \mathrm{~km}$ apart). All inhabitants are extremely poor, including the chiefs and the elders. Only men are hunters in the study area. 
Focus group discussions were organized in the same way in all villages, and were facilitated and translated by a person of the same ethnicity as the inhabitants of the village studied. Discussions focused on: (1) preferred wildlife species used for household consumption (i.e. those eaten more often) at the village level (not at the participants' own households), (2) preferred species used for income generation at the village level, and (3) observed changes in species' populations and potential explanations for these changes. We specifically asked participants to identify (and agree upon) the three most important species for household consumption or income generation. We also discussed hunting techniques. During discussions we clarified that by species for income generation we specifically asked about those killed for bushmeat. Some primates may be traded as pets and some pangolins for medicinal purposes, but we did not discuss these uses as they are not widespread in the study area (RB, pers. obs., 2018).

We used photos from available literature (e.g. Kingdon, 2006) to confirm which species the vernacular names used during the focus group discussions referred to. We also took photos of carcasses and showed them to Park staff to confirm species identity in some cases.

\section{Kindu market survey}

Our market survey took place in Kindu (c. 450,000 inhabitants; Population Data, 2018), the largest urban centre near Lomami National Park (Fig. 1) and a major trading centre for timber, bushmeat, agricultural products and minerals. The bushmeat market is open every day during the open season (October-June), during which it is legal to hunt and trade non-threatened species. We conducted the survey in October 2018, after the closed season (July-September). We conducted interviews with 30 vendors, which was c. 50\% of the vendors in the market during our study period. These 30 vendors participated in our survey on a voluntary basis, and their responses were kept anonymous. Although this is a relatively small number of vendors, the species accumulation curve (Supplementary Fig. 1) indicates that we captured the majority of species for sale. We gathered data on the number of species traded, their price and format (fresh/smoked), their origin (i.e. village), the volumes sold per week, and perceived changes over time in species' availability. Carcasses offered for sale were identified using photos and vernacular names, as in the village surveys. We also recorded age, gender, and socio-ethnic group of all vendors.

We gathered market data with a mixed approach: observation of market stall (which species a vendor had on her/his stall, and how many individuals of each) and vendor recall (we asked her/him to estimate how many carcasses of each species she/he usually sold per week during the open season, and if any species commonly sold were not in her/his market stall that day). We multiplied vendor recall estimate on weekly volumes by the number of weeks during the open season (30 weeks/year) to estimate annual trading volumes.

Although vendors mentioned that they also traded during the closed season, we did not ask them about volumes sold during that period and thus did not include those in our analysis. During the closed season bushmeat is not sold openly, but customers ask vendors in the vegetable market for it, and vendors retrieve the bushmeat from hidden places. Direct observation (counting numbers of species and individuals per day and vendor) was not possible during the closed season as vendors would suspect that we may work for the National Parks Authority (see Discussion for limitations of the study).

\section{Data analysis}

Species' scientific names and conservation status followed the IUCN Red List (IUCN, 2018).

To determine the effects of ethnicity on villagers' responses, the four villages of each ethnic group were pooled (villages of the same ethnic group were in close vicinity to each other). Estimated travel times by motorbike (these villages are not accessible by four-wheeled motor vehicles) to Kindu are as follows: Kusu 6.5 h, Kuti 7.5 h, Ngengele 3 h, Silwamba $5 \mathrm{~h}$, Tetela $6.5 \mathrm{~h}$ and Mbote $8 \mathrm{~h}$, with the latter two inaccessible by motorbike during most of the rainy season. We observed no differences between ethnic groups, nor by distance to Kindu. We therefore combined all 24 focus group discussions and report responses as per cent of the total.

For Kindu market data, we extrapolated volumes in number of carcasses, biomass and monetary value of the annual harvest from the mean number of carcasses traded per week per vendor (from vendor recall), multiplied by number of vendors, similar to Gonedelé et al. (2017). We extracted mean biomass for each species from Kingdon (2006), assuming equal distribution of male and female individuals amongst the carcasses. A large proportion of carcasses were smoked and therefore our prices per $\mathrm{kg}$ (compared with beef or chicken) and annual retail values are approximate. We report price per smoked rather than fresh carcass, because we only found a few fresh carcasses of some species. Our estimates represent a minimum volume and retail value of bushmeat trade in Kindu because we calculated annual volumes excluding the closed season (although most vendors mentioned trading during that season), and we only surveyed c. $50 \%$ of the vendors in the market and computed annual volumes using this number of vendors. Because study participants did not mention any change in species' presence or abundance related to the creation of the Park in 2016, we do not discuss this further. 


\section{Results}

\section{Village surveys}

A total of 22 species (all mammals) were mentioned as important for bushmeat in our village surveys (Table 1). Fifteen were considered important for household consumption (consumed most often) whereas 16 were considered important for income generation (Table 1). The most important species for household consumption (mentioned in $>40 \%$ of the villages sampled) were the African brush-tailed porcupine Atherurus africanus, Peters's duiker Cephalophus callipygus, bay duiker Cephalophus dorsalis and red river hog Potamochoerus porcus. The most important species for income generation (mentioned in $>40 \%$ of the villages sampled) were the same, except for the porcupine, which was considered less important for income generation (Table 1). In general, a greater number of smaller species $(<10 \mathrm{~kg})$ were mentioned for household consumption (e.g. rodents such as the Gambian pouched rat Cricetomys gambianus and African giant squirrel Protoxerus stangeri) whereas a greater number of large species $(>30 \mathrm{~kg})$ were mentioned for income generation (e.g large ungulates including the common duiker Sylvicapra grimmia, harnessed bushbuck Tragelaphus scriptus and sitatunga Tragelaphus spekii; Table 1). Participants reported selling large ungulates because most people in Kindu prefer them as 'they are tastier'. Bushmeat, small fish and caterpillars (the latter only available in September-December) were reported to be the main sources of protein in all villages studied (animal rearing is limited in this area).

There were no major differences in the species mentioned by the different ethnic groups, but Mbote sometimes exchanged carcasses for objects (e.g. shoes or clothes) rather than money. Respondents mentioned that they mostly sold their carcasses in the towns of Dikanjo, Lokando, Bafundo and Kindu (Fig. 1). Respondents in all villages reported hunting to be their main income generating activity, with the money being used to pay for school fees, medicines or clothes.

In many villages, participants mentioned declines of some species (African brush-tailed porcupine, Peters's and bay duiker, and guenons Cercopithecus sp.; Table 1). Hunters reported they had to travel greater distances, to locations closer to or inside the Park's core zone, to find these species. They also mentioned that certain species had nearly disappeared, notably the forest elephant, African buffalo Syncerus caffer and bongo Tragelaphus eurycerus ( 96,50 and $42 \%$ of the villages sampled, respectively). According to the villagers, wildlife population declines were related to overhunting, which they attributed to four factors: (1) an increased number of foreigners (Congolese from other ethnic groups who are not local to the study area) hunting in the area, (2) increased use of firearms, primarily by foreign hunters, (3) lack of respect for the closed season, and (4) lack of respect for traditional regulations that do not allow hunting certain species (e.g. bonobos, pangolins, tortoises). An increased use of firearms, particularly by wealthier foreign hunters, was attributed to the fact that it makes hunting gregarious animals easier and because prey caught in traps can be stolen. The Congolese Institute for Nature Conservation (Institut Congolais pour la Conservation de la Nature) is responsible for enforcing the bushmeat hunting and trading ban during the closed season. However, the financial and human resources needed to patrol the Park and buffer zone are lacking, and enforcement is ineffective.

At least five species hunted for bushmeat are of conservation concern (i.e. categorized as threatened on the IUCN Red List; Table 1). A sixth species could be the newly described, Vulnerable lesula Cercopithecus lomamiensis, which is endemic to Lomami National Park. Guenons Cercopithecus spp. are used for bushmeat in Kindu, but we could not always confirm the species because of the poor quality of smoked carcasses. During the focus group discussions we realized there was a misconception about hunting threatened species: because all species inside the Park's core zone were protected (hunting is forbidden), villagers thought they were allowed to hunt any species in the Park's buffer zone (e.g. including the bonobo).

\section{Market survey}

A total of 18 species were commercialized during our study period, 11 of which had been mentioned as important for income generation during the village surveys (Table 1). Almost all were mammals, including nine artiodactyls, six primates, one rodent and one carnivore. There was one species of crocodile and no birds (Table 1). Six species were traded by $>40 \%$ of the vendors: the African brush-tailed porcupine, blue duiker Cephalophus monticola, bay duiker, red river hog, red-tailed monkey Cercopithecus ascanius, and the sitatunga. Most species were sold as whole carcasses (except the porcupine and sitatunga, which were sometimes sold by quarters), and in smoked form (Table 1). The cheapest species (per individual) was an unidentified guenon and the most expensive was the red river hog. In general, smaller species were cheaper than larger ones (Table 1), but prices also depended on the size of individual carcasses, with larger ones being more expensive. Vendors mentioned that they mostly traded smoked carcasses because they were easier to transport. The roads around Lomami National Park are impassable by four-wheeled motor vehicles, and some are inaccessible even by motorbike during the rainy season. Only nine (of 30) vendors mentioned they did not trade certain species during the closed season, but still traded others during that period.

Most vendors in Kindu buy carcasses from major retailers. Retailers travel to towns (mostly Dikanjo, Katopa and 
TABLE 1 Species reported during the village surveys as being important for household consumption or income generation, perceived as having declining populations or having become rare, and observed in Kindu bushmeat market.

\begin{tabular}{|c|c|c|c|c|c|c|c|c|c|c|}
\hline \multirow[b]{2}{*}{ Species (by Order) } & \multirow[b]{2}{*}{$\begin{array}{l}\text { Size } \\
\text { class } \\
(\mathrm{kg})\end{array}$} & \multirow[b]{2}{*}{ Status $^{3}$} & \multicolumn{4}{|c|}{ Village surveys $^{1}$} & \multicolumn{4}{|l|}{ Kindu market $^{2}$} \\
\hline & & & $\begin{array}{l}\text { Household } \\
\text { consumption }\end{array}$ & $\begin{array}{l}\text { Income } \\
\text { generation }\end{array}$ & $\begin{array}{l}\text { Perceived } \\
\text { decline }\end{array}$ & $\begin{array}{l}\text { Perceived } \\
\text { as rare }\end{array}$ & $\begin{array}{l}\text { Mean body } \\
\text { weight }(\mathrm{kg})^{4}\end{array}$ & $\begin{array}{l}\text { Carcasses sold } \\
\text { (smoked or fresh) }\end{array}$ & $\begin{array}{l}\text { Price per } \\
\text { smoked carcass } \\
\text { (USD) }\end{array}$ & $\begin{array}{l}\text { Vendors per- } \\
\text { ceive decline } \\
\text { (\%) }\end{array}$ \\
\hline \multicolumn{11}{|l|}{ Rodentia } \\
\hline $\begin{array}{l}\text { African brush-tailed porcupine } \\
\text { Atherurus africanus }\end{array}$ & $<10$ & LC & 13 & 3 & 18 & 0 & $1.5-4(\mathrm{~F} / \mathrm{M})$ & Smoked/fresh & 7 & 75 \\
\hline $\begin{array}{l}\text { Gambian pouched rat } \\
\text { Cricetomys gambianus }\end{array}$ & $<10$ & LC & 1 & 0 & 1 & 0 & & & & \\
\hline \multicolumn{11}{|l|}{ Artiodactyla } \\
\hline $\begin{array}{l}\text { Peters's duiker } \\
\text { Cephalophus callipygus }\end{array}$ & $10-50$ & LC & 10 & 10 & 20 & 1 & $16-23(\mathrm{~F} / \mathrm{M})$ & Smoked & 27 & 100 \\
\hline $\begin{array}{l}\text { Bay duiker } \\
\text { Cephalophus dorsalis }\end{array}$ & $10-50$ & NT & 10 & 13 & 17 & 0 & 15-24 (F/M) & Smoked & 30 & 80 \\
\hline $\begin{array}{l}\text { Blue duiker } \\
\text { Cephalophus monticola }\end{array}$ & $<10$ & LC & 4 & 3 & 9 & 0 & 3.5-9 (F/M) & Smoked/fresh & 8 & 80 \\
\hline $\begin{array}{l}\text { Red river hog } \\
\quad \text { Potamochoerus porcus }\end{array}$ & $>50$ & LC & 13 & 13 & 5 & 1 & 45-115 (F/M) & Smoked/fresh & 54 & 77 \\
\hline $\begin{array}{l}\text { Common duiker } \\
\text { Sylvicapra grimmia }\end{array}$ & $10-50$ & LC & 0 & 2 & 1 & 0 & $\begin{array}{l}12-25.5(\mathrm{~F}) \\
11-21.5(\mathrm{M})\end{array}$ & Smoked & 43 & 100 \\
\hline $\begin{array}{l}\text { African buffalo } \\
\text { Syncerus caffer }\end{array}$ & $>50$ & NT & 0 & 2 & 0 & 12 & & & & \\
\hline $\begin{array}{l}\text { Harnessed bushbuck/kéwel } \\
\text { Tragelaphus scriptus }\end{array}$ & $>50$ & LC & 0 & 3 & 0 & 1 & $\begin{array}{l}24-60(\mathrm{~F}) \\
30-80(\mathrm{M})\end{array}$ & Smoked & 20 & 30 \\
\hline $\begin{array}{l}\text { Sitatunga } \\
\quad \text { Tragelaphus spekii }\end{array}$ & $10-50$ & LC & 2 & 7 & 5 & 1 & $\begin{array}{l}40-85(\mathrm{~F}) \\
80-130(\mathrm{M})\end{array}$ & Smoked/fresh & 45 & 85 \\
\hline \multicolumn{11}{|l|}{ Primates } \\
\hline Bonobo Pan paniscus & $>50$ & EN & 0 & 1 & 0 & 1 & & & & \\
\hline Cercopithecus spp. ${ }^{5}$ & $<10$ & Unknown & 4 & 3 & 18 & 0 & Unknown & Smoked & 6 & 60 \\
\hline $\begin{array}{l}\text { Angola colobus } \\
\text { Colobus angolensis }\end{array}$ & $10-50$ & LC & 2 & 0 & 1 & 2 & 9-20 (F/M) & Smoked & 20 & 100 \\
\hline
\end{tabular}


Table 1 (Cont.)

\begin{tabular}{|c|c|c|c|c|c|c|c|c|c|c|}
\hline \multirow[b]{2}{*}{ Species (by Order) } & \multirow[b]{2}{*}{$\begin{array}{l}\text { Size } \\
\text { class } \\
(\mathrm{kg})\end{array}$} & \multirow[b]{2}{*}{ Status $^{3}$} & \multicolumn{4}{|c|}{ Village surveys $^{1}$} & \multicolumn{4}{|l|}{ Kindu market $^{2}$} \\
\hline & & & $\begin{array}{l}\text { Household } \\
\text { consumption }\end{array}$ & $\begin{array}{l}\text { Income } \\
\text { generation }\end{array}$ & $\begin{array}{l}\text { Perceived } \\
\text { decline }\end{array}$ & $\begin{array}{l}\text { Perceived } \\
\text { as rare }\end{array}$ & $\begin{array}{l}\text { Mean body } \\
\text { weight (kg) }\end{array}$ & $\begin{array}{l}\text { Carcasses sold } \\
\text { (smoked or fresh) }\end{array}$ & $\begin{array}{l}\text { Price per } \\
\text { smoked carcass } \\
\text { (USD) }\end{array}$ & $\begin{array}{l}\text { Vendors per- } \\
\text { ceive decline } \\
\text { (\%) }\end{array}$ \\
\hline $\begin{array}{l}\text { Dent's mona monkey } \\
\text { Cercopithecus denti }\end{array}$ & $<10$ & $\mathrm{LC}$ & & & & & $3-6(\mathrm{~F} / \mathrm{M})$ & Smoked/fresh & 12 & 30 \\
\hline $\begin{array}{l}\text { Black crested mangabey } \\
\text { Lophocebus aterrimus }\end{array}$ & $<10$ & VU & & & & & $\begin{array}{l}4-7(\mathrm{~F}), 6-11 \\
(\mathrm{M})\end{array}$ & Smoked & 11 & 75 \\
\hline $\begin{array}{l}\text { Thollon's red colobus } \\
\text { Piliocolobus tholloni }\end{array}$ & $<10$ & VU & 3 & 0 & 1 & 0 & $\begin{array}{l}7-9(F), 9-13 \\
(M)\end{array}$ & Smoked & 11 & 50 \\
\hline \multicolumn{11}{|l|}{ Carnivora } \\
\hline $\begin{array}{l}\text { Servaline genet } \\
\text { Genetta servalina }\end{array}$ & $<10$ & $\mathrm{LC}$ & & & & & $1-2(\mathrm{~F} / \mathrm{M})$ & Smoked & 13 & 100 \\
\hline \multicolumn{11}{|l|}{ Tubulidentata } \\
\hline $\begin{array}{l}\text { Aardvark Orycteropus afer } \\
\text { Pholidota }\end{array}$ & $>50$ & $\mathrm{LC}$ & 0 & 4 & 4 & 1 & & & & \\
\hline $\begin{array}{l}\text { Black-bellied pangolin/ } \\
\text { long-tailed pangolin } \\
\text { Uromanis tetradactyla }\end{array}$ & $<10$ & $\mathrm{VU}$ & 2 & 1 & 0 & 0 & & & & \\
\hline \multicolumn{11}{|l|}{ Crocodilia } \\
\hline $\begin{array}{l}\text { Dwarf crocodile } \\
\text { Osteolaemus tetraspis }\end{array}$ & $10-50$ & $\mathrm{VU}$ & & & & & $\begin{array}{l}13.6-31.8(\mathrm{~F}) \\
18-45.4(\mathrm{M})\end{array}$ & Smoked & 10 & 100 \\
\hline
\end{tabular}

${ }^{1}$ Values refer to number of villages (total $n=24$ ) in which the species was mentioned. Blank cells denote species that were not mentioned in village surveys.

${ }^{2}$ Blank cells denote species that were not observed on the market.

${ }^{3}$ Conservation status according to IUCN, 2018. LC, Least Concern; NT, Near Threatened; VU, Vulnerable; EN, Endangered.

${ }^{4}$ From Kingdon (2006), except the dwarf crocodile from San Diego Zoo Global (2015). F, female; M, male.

${ }^{5}$ Cercopithecus spp. could be the newly described Vulnerable Cercopithecus lomamiensis endemic to Lomami National Park, but the species could not be confirmed because of the poor quality of the smoked carcasses. 

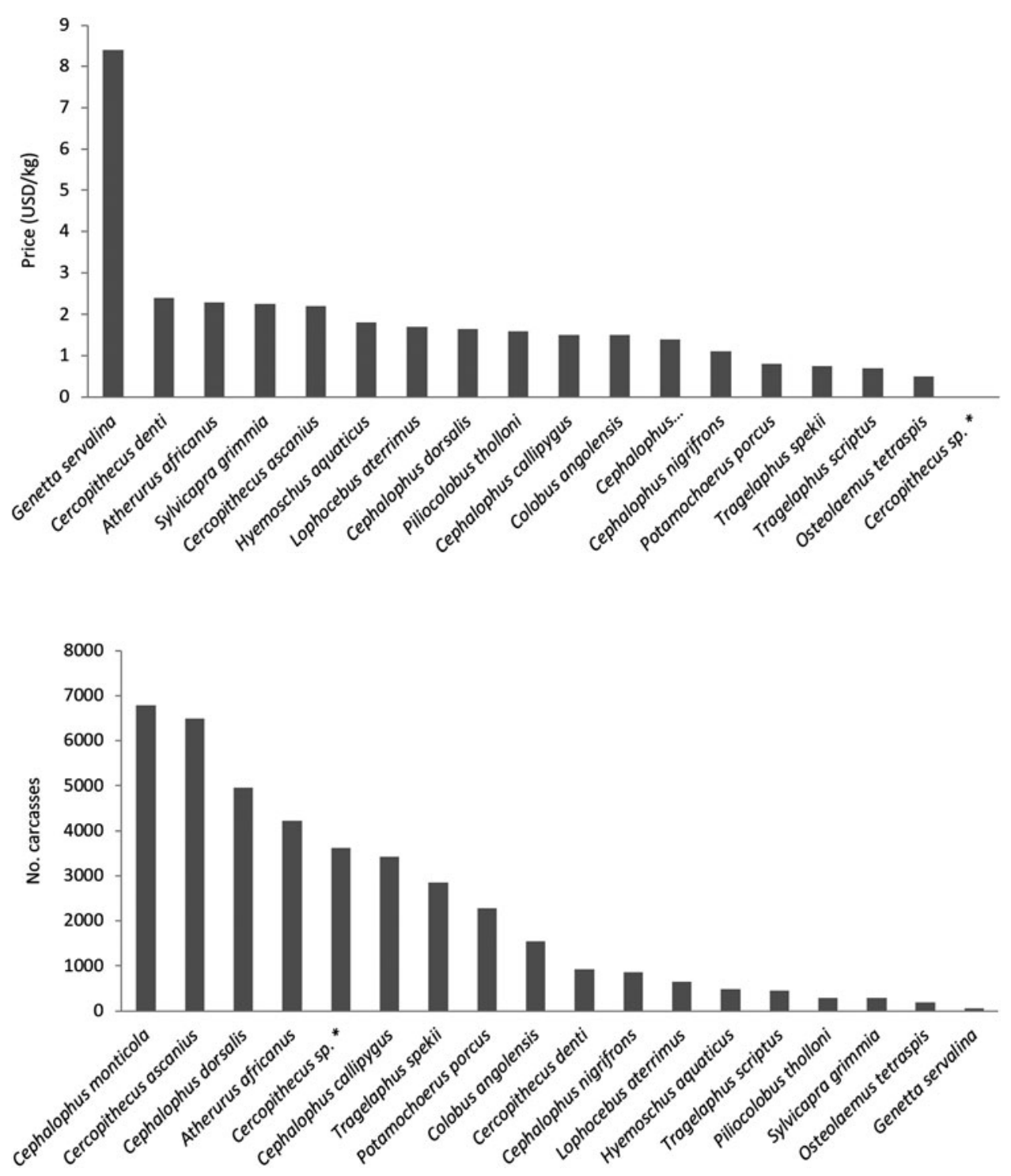

FIG. 2 Estimated price of bushmeat of the different species traded in Kindu market. Guenons Cercopithecus spp. could not be determined to species level because of the poor quality of smoked carcasses.
FIG. 3 Estimated number of carcasses of the different species traded annually during the open season in Kindu market. Guenons Cercopithecus spp. could not be determined to species level because of the poor quality of smoked carcasses.
Oluo; Fig. 1) to purchase carcasses directly from hunters, who are either their established business partners or opportunistic hunters present in the town that day. A small number of vendors in Kindu reported their husband or other male family member hunted regularly and provided them with carcasses to sell. Many hunters who partner with retailers are not from the ethnic groups living in the area, but are what local people in the focus group discussions referred to as foreign hunters.

Per weight, the servaline genet Genetta servalina was the most expensive species, whereas the dwarf crocodile Osteolaemus tetraspis was the cheapest, and most species cost USD 1.50-2.50 per kg (Fig. 2). However, the crocodile prices were probably underestimated because we only found two very small individuals in the market during our survey, which were unlikely to have the mean weight reported in the literature. For most species, our estimated price per $\mathrm{kg}$ is probably an underestimate as we used the mean weight of adults (and some individuals sold may have been juveniles). We also used the mean of female and male weights for our calculations (which can differ significantly in some species), without attempting to determine the sex of individual carcasses. The use of the servaline genet in rituals may explain its high price even when traded for bushmeat. Compared with available alternative protein, bushmeat was much cheaper than beef (c. USD 6.50 per kg) or chicken (c. USD 7.50 per $\mathrm{kg}$ ), although direct comparison is difficult because beef is usually traded as pieces of meat rather than as whole carcasses.

We estimated that the 30 vendors surveyed traded a total of $>40,000$ carcasses during the open season annually, with an annual retail value of USD 725,00o. We estimated that one-third of the traded carcasses were of two species, the blue duiker and red-tailed monkey (Fig. 3). The species traded in greatest numbers were also those traded by most vendors, together with guenons and Peters's duiker (Table 1, 
Fig. 3). All species observed in the market were traded to be consumed as food, but some may also be used for medicinal or ritual purposes (e.g. the dwarf crocodile and servaline genet; RB, pers. obs., 2018).

For 15 species, $>50 \%$ (and sometimes $100 \%$ ) of the vendors trading them reported declines (Table 1). Vendors mentioned these species were becoming difficult to find (lower numbers offered for sale in villages or brought in by family members), and that their price at the market had increased in previous years. Four species commercialized in Kindu are categorized as threatened on the IUCN Red List (Table 1). All vendors were small-scale retailers (i.e. they had not hunted the animals themselves). They were mostly women aged 30-50 years, from the Kusu or Ngengele ethnic groups. Bushmeat trade was their main livelihood activity.

\section{Discussion}

\section{Village-level consumption}

In the villages around Lomami National Park smaller species $(<10 \mathrm{~kg})$ were mostly used for household consumption whereas larger ones $(>30 \mathrm{~kg})$ were mostly sold to generate income, as has been reported from other areas in DRC (e.g. Kisangani; van Vliet et al., 2015). However, the fact that some large species such as the red river hog were consumed at the household level suggests that they are relatively abundant in the study area. Local hunters check their traps often to avoid theft, so large animals are not eaten in households because carcasses were left unattended for an extended period and are rotten.

There were no major differences between ethnic groups in the species important for household consumption, which indicates similar taste preferences. This is at variance with studies elsewhere (e.g. Bioko Island, Equatorial Guinea; Fa et al., 2002).

Villagers reported declines of certain species and an increased use of firearms. In the northern Republic of the Congo hunters also mentioned declines in the abundance of most species targeted for bushmeat (Mavah et al., 2018). Increased use of firearms has been reported in numerous locations in Africa, including Kisangani, northern Gabon, Equatorial Guinea and around Dja Biosphere Reserve in Cameroon (Kümpel et al., 2008; van Vliet \& Nasi, 2008; van Vliet et al., 2012; Avila et al., 2019). In Kisangani, an increase in small diurnal monkeys in the bushmeat market over time was related to increased use of firearms (van Vliet et al., 2012). In our study area the relatively widespread use of firearms could explain the numerous primates observed in Kindu market. Increased use of firearms can lead to a decrease in the abundance of small diurnal monkeys and the local depletion of some species (e.g. in Equatorial Guinea; Kümpel et al., 2008).

\section{Urban market sales}

Species traded in Kindu included nine artiodactyls, six primates, one rodent, one carnivore and one crocodile. Several studies reported mammals to be the most hunted group, with reptiles, birds and amphibians being less important (see Petrozzi et al., 2016 for a review). However, most market surveys focus on bushmeat and may overlook other markets (e.g. of tortoises mostly used for medicine or rituals; Petrozzi et al., 2016). Preliminary observations in the medicinal market of Kindu indicate that no wildlife is traded there (RB, pers. obs., 2018).

We documented a total of 18 species in Kindu. Greater numbers were reported from Kisangani and Brazzaville in the Republic of the Congo (24 and 35 species, respectively; Mbete et al., 2011; van Vliet et al., 2017). Some authors have argued that with higher anthropogenic pressures, fewer large-bodied animals but a higher number of species are sold at markets (Cowlishaw et al., 2005; Fa, 2007). Therefore, the lower species diversity observed in Kindu, together with the presence of large-bodied animals and low number of rodents, suggests a moderate anthropogenic pressure in our study area.

In Kindu, the species most commonly traded were the African brush-tailed porcupine, blue and bay duikers, red river hog, red-tailed monkey and the sitatunga. In Basankusu, a town in north-western DRC, the red-tailed monkey and red river hog were two of the four most commonly traded species (Dupain et al., 2012). In Kisangani and in Brazzaville, the blue and bay duiker and the African brush-tailed porcupine were the most commonly traded species (Mbete et al., 2011; van Vliet et al., 2012). In the Cross-Sanaga region of Nigeria and Cameroon the porcupine was also one of the most commonly traded species (Macdonald et al., 2012). In Kindu most carcasses were smoked, as has been reported elsewhere (Mbete et al., 2011; Macdonald et al., 2012; van Vliet et al., 2012). The proportion of smoked meat is often interpreted as an indication of the size of the hunting catchment area. However, the high proportion of smoked meat in Kindu market could also indicate poor transport conditions or lack of facilities to conserve meat, as reported for Kisangani (van Vliet et al., 2012).

Overall, our findings suggest that in Kindu smoked bushmeat is not a luxury product, but rather a common product sold at a low price year-round. This was in accordance with observations made in Kisangani and Bangui (van Vliet et al., 2012; Fargeot et al., 2017). In contrast, in urban Ghana, Gabon and Nigeria bushmeat is a luxury product (Ladele et al., 1996; Starkey, 2004; Cowlishaw et al., 2005).

Our study approach has some limitations. Firstly, vendor recall accuracy may have been limited, as we asked vendors to estimate weekly volumes just after the closed season. Also, vendors reported they sold the same selection of species throughout the year, which we were unable to verify. 
Prices per kg are likely to be underestimated, as carcasses sold could have been juvenile, or mostly females. Secondly, our estimates represent a minimum volume of bushmeat traded in Kindu as we calculated annual volumes excluding the closed season, and we only surveyed c. 50\% of the vendors in the market. Another methodological caveat is that we used only focus group discussions at the village level. Such focus groups may not be representative of the whole population in a region, and results should not be generalized (Cruz-Garcia et al., 2019). In any future research, focus group discussions could be combined with other complementary methods such as individual interviews and individual ranking exercises. Further insights could be gained from interviewing major retailers and foreign hunters.

\section{Implications}

Our findings indicate that bushmeat household consumption and trade include several species of conservation concern, a matter that requires intervention. The first issue to address is the misconception about which species can be legally hunted in the Park's buffer zone. Lomami National Park was created relatively recently (in July 2016) and local communities appear to be ignorant of hunting restrictions in the buffer zone. Before the Park was created, several awareness raising campaigns discussed the Endangered status of the bonobo and the fact that it should not be hunted, which seems to have reduced the numbers of specimens openly traded in Kindu (we did not observe this species in Kindu during our market survey, but it was reported there in 2009; Hart, 2009). It is possible that the bonobo is still traded secretly, but we were unable to confirm this. New awareness campaigns are needed to clarify which species can legally be hunted in the buffer zone.

The widespread use of firearms enables hunters to target specific species and individuals, whereas traditional hunting with snares is opportunistic and less targeted. This opens opportunities for awareness raising and education amongst hunters, particularly with respect to primates. Because they are diurnal, primates are mostly hunted during the day (Macdonald et al., 2012), whereas other animals such as duikers are often hunted at night. During daylight hours, primate species can easily be identified by sight, and hunters could avoid targeting threatened species. Awareness campaigns should be linked with the development and enforcement of hunting regulations that benefit local, not foreign hunters. If licensed local hunters could be given a quota that they are responsible for, it would be in their interest to not exceed the quota and to report unlicensed hunters, to help secure the long-term persistence of the wildlife populations on which their livelihoods depend (Macdonald et al., 2012).

Increased collaboration with traditional authorities, who have considerable influence and command local respect, could also help reinforce traditional rules forbidding hunting of certain species, such as pangolins. Drawing on the capacity of such authorities to restrict access to markets and firearms has provided encouraging results in other areas of DRC (de Merode et al., 2004). Furthermore, greater control of bushmeat trade is needed in Kindu and other towns near Lomami (e.g. Dikanjo, Lokando, Bafundo). Given the limited number of roads accessible by motor vehicles in the study area, road checkpoints could be useful for monitoring bushmeat trade and enforcing restrictions.

Beyond the species of conservation concern, several other species were perceived as declining by vendors in Kindu, but not by villagers. It is possible that villagers only highlighted the species they thought were close to extinction (elephant, bongo, buffalo), and not those whose populations had declined to a lesser extent. It has been suggested that hunting of resilient species such as the blue duiker and African brush-tailed porcupine could be allowed, but that other species such as the red river hog and small diurnal monkeys require more conservation attention (van Vliet \& Nasi, 2008). Future biodiversity surveys in the Park should focus on the species mentioned as declining in Kindu but not in the villages, to clarify population trends.

Our results indicate that around Lomami National Park bushmeat is used as food and as a source of income. Access to protein from domestic animals is limited: goats, sheep, pigs and poultry are rare, and there is no formal livestock husbandry or veterinary provision. The lack of cattle rearing in the region is attributed to the presence of the tsetse fly, which transmits trypanosomiasis. For preferences to develop (e.g. for domestic meat), a product must first be reasonably familiar (Turrell, 1998). Although the consumption of domestic meat is currently rare in the study area, most villagers reported an interest in rearing goats, pigs and poultry, if funds and training could be provided to facilitate this. In Kahuzi-Biega National Park the rearing of cavies has been successfully promoted to meet household demands for protein and to generate income (Thierry et al., 2018). The need to support domestic meat production is included in the National Bushmeat Strategy for DRC (ICCN, 2009) and the technical expertise is available, but access to loans to help people start rearing animals, and support such as veterinary care, are needed (van Vliet et al., 2012). Caterpillar rearing could also be considered as an alternative source of protein. For example, the caterpillars of the African moth Bunaeopsis aurantiaca are highly nutritious (433 kcal/ 100 g; Muvundja et al., 2013). They occur naturally on the sugar plum tree Uapaca guineensis, which is abundant in Lomami National Park. Caterpillars can be smoked and dried, facilitating storage and transport.

Bushmeat trade around Lomami National Park currently appears to be limited to adjacent towns and the city of Kindu. But the situation is likely to change if roads around Kindu and Lomami National Park are upgraded and Kindu 
airport opens to international flights, as currently planned by the government. Improved infrastructure will probably increase not only economic prosperity but also the human population of Kindu, and therefore the demand for meat protein. Although some authors have argued that so-called westernization of taste preferences in Africa's urban areas could decrease the demand for bushmeat, which may be considered 'dirty meat' or a sign of cultural primitivity by urban communities (Luiselli et al., 2019), recent studies from DRC suggest urban populations consume bushmeat not only because they lack access to cheap alternatives but also because they prefer the taste (van Vliet et al., 2012). The same study from Kisangani showed new areas being exploited for bushmeat after road infrastructure improved (van Vliet et al., 2012).

Our survey captures the situation at a specific point in time, and research for Kisangani demonstrated that species commercialized, total biomass and prices of bushmeat vary over time, with changes related to overhunting in some areas, conflict, and alternative sources of protein becoming more affordable (van Vliet et al., 2017). Nevertheless, our survey provides an important baseline for future monitoring and can help inform management interventions for Lomami National Park and its surroundings.

\section{Conclusions}

This study confirms the importance of bushmeat for local populations around Lomami National Park and in Kindu city, where we estimated $>40,000$ carcasses of 18 species, with a retail value of USD 725,000 , are traded annually. Such case studies are important for designing management interventions at the local and regional levels, and can be used to assess change over time and promote future research. Lomami National Park was created to safeguard the outstanding biodiversity of the study area (e.g. the lesula Cercopithecus lomamiensis, endemic to this Park) and to facilitate sustainable development for communities living near the protected area. Our findings, recently shared with study participants and conservation organizations working in the area, will help inform the management interventions needed to achieve these goals.

Acknowledgements We thank all study participants, especially the village chiefs, who helped organize the focus group discussions, our field assistants and translators P. Kinyama and E. Bushiri, the managers of Lomami National Park, the Deutsche Gesellschaft für Internationale Zusammenarbeit office and Deutsche Forstservice $\mathrm{GmbH}$ team in Kindu, and two anonymous reviewers for their critiques. This research was funded by The Rufford Foundation, UK. GI was supported by the Percy Sladen Memorial Fund.

Author contributions Conception and design: BR, GI, ACS; data collection: BR, CU; data analysis: all authors; writing: GI, ACS; revision: all authors.

\section{Conflicts of interest None.}

Ethical standards This research abided by the Oryx guidelines on ethical standards. Because it was conducted outside a protected area, no official research permit was required, but Park managers were informed and were supportive of the research. We informed local authorities before starting our research and obtained prior informed consent from all study participants, who participated on a voluntary basis. Interviewees' responses were kept anonymous. After we completed the study, we shared a non-academic report with both communities and Park managers.

\section{References}

Abernethy, K.A., Coad, L., Taylor, G., Lee, M.E. \& Maisels, F. (2013) Extent and ecological consequences of hunting in Central African rainforests in the twenty-first century. Philosophical Transactions of the Royal Society B, 368, 20120303.

Allebone-Webi, S.M., Kümpel, N.F., Rist, J., Cowlishaw, G., Rowcliffe, J.M. \& Milner-Gulland, E.J. (2011) Use of market data to assess bushmeat hunting sustainability in Equatorial Guinea. Conservation Biology, 25, 597-606.

Avila, E., Tagg, N., Willie, J., Mbohli, D., Farfan, M.A., Vargas, J.M. et al. (2019) Interpreting long-term trends in bushmeat harvest in southeast Cameroon. Acta Oecologica, 9, 57-65.

Bennett, E., Eves, H., Robinson, J. \& Wilkie, D. (2002) Why is eating bushmeat a biodiversity crisis? Conservation in Practice, 3, 28-29.

Brodie, J.F. \& Gibbs, H. (2009) Bushmeat hunting as climate threat. Science, 326, 364-365.

Cowlishaw, G., Mendelson, S. \& Rowcliffe, J.M. (2005) Evidence for post-depletion sustainability in a mature bushmeat market. Journal of Applied Ecology, 42, 460-468.

Cruz-Garcia, G.S., Cubillos, M.V., Torres-Vitolas, C., Harvey C.A., Shackleton, C.M., Schreckenberg, K. et al. (2019) He says, she says: ecosystem services and gender among Indigenous communities in the Colombian Amazon. Ecosystem Services, $37,100921$.

de Merode, E., Homewood, K. \& Cowlishaw, G. (2004) The value of bushmeat and other wild foods to rural households living in extreme poverty in Democratic Republic of Congo. Biological Conservation, 118, 573-581.

Dupain, J., Nackoney, J., Vargas, J.M., Johnson, P.J., Farfan, M.A., Bofaso, M. et al. (2012) Bushmeat characteristics vary with catchment conditions in a Congo market. Biological Conservation, $146,32-40$.

FA, J.E. (2007) Bushmeat markets - white elephants or red herrings? In Bushmeat and Livelihoods: Wildlife Management and Poverty Reduction (eds G. Davies \& D. Brown), pp. 47-6o. Conservation Science and Practice, Volume 2. Blackwell Publishing, Oxford, UK.

Fa, J.E., Garcia Yuste, J.E. \& Castelo, R. (2000) Bushmeat markets on Bioko Island as a measure of hunting pressure. Conservation Biology, 14, 1602-1613.

Fa, J.E., Peres, C.A. \& Meeuwig, J. (2002) Bushmeat exploitation in tropical forests: an intercontinental comparison. Conservation Biology, 16, 232-237.

Fa, J.E., Currie, D. \& Meeuwig, J.J. (2003) Bushmeat and food security in the Congo Basin: linkages between wildlife and people's future. Environmental Conservation, 30, 71-78.

Fa, J.E., Olivero, J., Farfán, M.Á., Márquez, A.L., Duarte, J., NACKOney, J. et al. (2015) Correlates of bushmeat in markets and depletion of wildlife. Conservation Biology, 29, 805-815. 
Fargeot, C., Drouet-Hoguet, N. \& Le Bel, S. (2017) The role of bushmeat in urban household consumption: insights from Bangui, the capital city of the Central African Republic. Bois et Forêts des Tropiques, 332, 31-42.

Golden, C.D., Fernald, L.C., Brashares, J.S., Rasolofoniaina, B.R. \& KREMEN, C. (2011) Benefits of wildlife consumption to child nutrition in a biodiversity hotspot. Proceedings of the National Academy of Sciences of the United States of America, 108, 19653-19656.

Gonedelé, S.B., Koné, I., Béné, J.C.K., Bitty, E.A., Yao, K.A., Kouassi, B.A. \& Gaubert, P. (2017) Bushmeat hunting around a remnant coastal rainforest in Côte d'Ivoire. Oryx, 51, 418-427.

Hart, J.A. (2009) A Disaster Averted? The Bushmeat Crisis in Maniema Province. Report prepared by the Fondation Lukuru, Kinshasa, Democratic Republic of the Congo. bonoboincongo.com [accessed 20 December 2018].

iCCN (Institut Congolais pour la Conservation de la Nature) (2009) Contribution au Processus d'Élaboration de la Stratégie et du Plan d'Action Nationale sur la 'Viande de Brousse'. Rapport de l'Atelier, 23-24 Septembre 2009, Kinshasa. TRAFFIC, Paris, France.

ICCN (2012) Plan d'Orientation de Gestion. Volume I: Etat des Lieux, Version Definitive. GFA Consulting Group GmbH, Kinshasa, Democratic Republic of the Congo.

IUCN (2018) The IUCN Red List of Threatened Species. Version 2018-2. iucnredlist.org [accessed 20 December 2018].

Kingdon, J. (2006) Guide des Mammifères d'Afrique. Delachaux et Niestlé SA, Paris, France.

Kümpel, N.F., Milner-Gulland, E.J., Rowcliffe, J.M. \& Cowlishaw, G. (2008) Impact of gun-hunting on diurnal primates in continental Equatorial Guinea. International Journal of Primatology, 29, 1065-1082.

Kümpel, N.F., Milner-Gulland, E.J., Cowlishaw, G. \& Rowcliffe, J.M. (2010) Assessing sustainability at multiple scales in a rotational bushmeat hunting system. Conservation Biology, $24,861-871$.

Ladele, A.A., Joseph, K., Oмоtesho, O.A., \& Ijaiya, T.O. (1996) Sensory quality ratings, consumption pattern and preference for some selected meat types in Nigeria. International Journal of Food Sciences and Nutrition, 47, 141-145.

Luiselli, L., Hema, E.M., Segniagbeto, G.H., Ouattara, V., Eniang, E.A., Di Vittorio, M. et al. (2019) Understanding the influence of non-wealth factors in determining bushmeat consumption: results from four West African countries. Acta Oecologica, 94, 47-56.

Macdonald, D.W., Johnson, P.J., Albrechtsen, L., Seymour, S., Dupain, J., Hall, A. \& FA, J.E. (2012) Bushmeat trade in the Cross-Sanaga rivers region: evidence for the importance of protected areas. Biological Conservation, 147, 107-114.

Maisels, F., Keming, E., Kemei, M. \& Toh, C. (2001) The extirpation of large mammals and implications for montane forest conservation: the case of the Kilum-Ijim Forest, North-west Province, Cameroon. Oryx, 35, 322-331.

Mavah, G.A., Funk, S.M., Child, B., Swisher, M.E., Nasi, R., $F_{A}$, J.E. et al. (2018) Food and livelihoods in park-adjacent communities: the case of the Odzala Kokoua National Park. Biological Conservation, 222, 44-51.
Mbete, R.A., Banga-Mboko, H., Racey, P., Mfoukou-Ntsakala, A., NGanga, I., Vermeulen, C. et al. (2011) Household bushmeat consumption in Brazzaville, the Republic of the Congo. Tropical Conservation Science, 4, 187-202.

Mushagalusa, B.R. (2016) Impact de l'anthropisation sur les ressources forestières de la Réserve Naturelle d'Itombwe. BSc thesis, Université Catholique de Bukavu, Bukavu, Democratic Republic of the Congo.

Muvundja, F.A., Uwikunda, S.H., Mande, P., Alunga, L.G., Balagizi, K.I. \& Isumbisho, M.P. (2013) Valorisation de la chenille comestible Bunaeopsis aurantiaca dans la gestion communautaire des forêts du Sud-Kivu (République Démocratique du Congo). VertigO, Special Issue 17, 13929.

Petrozzi, F., Amori, G., Franco, D., Gaubert, F., Pacini, N., ENIANG, E.A. et al. (2016) Ecology of the bushmeat trade in West and Central Africa. Tropical Ecology, 57, 547-559.

Population Data (2018) Democratic Republic of the Congo. populationdata.net [accessed 20 December 2018].

San Diego Zoo Global (2015) Dwarf Crocodile (Osteolaemus tetraspis) Fact Sheet. San Diego, USA. ielc.libguides.com/sdzg/ factsheets/dwarf_crocodile [accessed 20 December 2018].

Schulze, K., Knights, K., Coad, L., Geldmann, J., Leverington, F., EAssom, A. et al. (2018) An assessment of threats to terrestrial protected areas. Conservation Letters, 11, e12435.

Siren, A.H. \& MachoA, J.D. (2008) Fish, wildlife and human nutrition in tropical forests: a fat gap? Interciencia, 33, 186-193.

STARKEY, M. (2004) Commerce and subsistence: the hunting, sale and consumption of bushmeat in Gabon. $\mathrm{PhD}$ thesis. Cambridge University, Cambridge, UK.

Taylor, G., Scharlemann, J.P.W., Rowcliffeet, M., Kümpel, N., Harfoot, M.B.J., FA, J.E. et al. (2015) Synthesising bushmeat research effort in West and Central Africa: a new regional database. Biological Conservation, 181, 199-205.

Thierry, K.M., Mugisho, A.B., Kababalire, F., Maass, B., Wimba, B.M.M. \& Амвоуа, C. (2018) Cavy between food security and conservation in Kahuzi Biega National Park, Sud-Kivu, DR Congo. Conference paper presented at: Tropentag 2018: Global Food Security and Food Safety: the Role of Universities, 17-19 September 2018, Ghent University, Ghent, Belgium.

Turrell, G. (1998) Socioeconomic differences in food preference and their influence on healthy food purchasing choices. Journal of Human Nutrition and Dietetics, 11, 135-149.

van Vliet, N. \& NASI, R. (2008) Hunting for livelihood in northeast Gabon: patterns, evolution, and sustainability. Ecology and Society, 13, 33. van Vliet, N., Nebesse, C., Gambalemoke, S., Akaibe, D. \& Nasi, R. (2012) The bushmeat market in Kisangani, Democratic Republic of Congo: implications for conservation and food security. Oryx, 46, 196-203.

van Vliet, N., Nebesse, C. \& Nasi, R. (2015) Bushmeat consumption among rural and urban children from Province Orientale,

Democratic Republic of Congo. Oryx, 49, 165-174.

van Vliet, N., Schulte-Herbrüggen, B., Muhindo, J., Nebesse, C. \& NASI, R. (2017) Trends in bushmeat trade in a postconflict forest town: implications for food security. Ecology and Society, 22, 35.

Wright, S.J., Zeballos, H., Domínguez, I., Gallardo, M.M., Moreno, M.C. \& IbÁñez, R. (200o) Poachers alter mammal abundance, seed dispersal and seed predation in a Neotropical forest. Conservation Biology, 14, 227-239. 